\title{
A CONCEPTUAL MODEL TO DETERMINE THE IMPACT OF OFF-SITE CONSTRUCTION ON LABOUR PRODUCTIVITY
}

\author{
Martin J. van Dijkhuizen', Ruben Vrijhoef ${ }^{2}$, and Hans L.M. Bakker ${ }^{3}$
}

\begin{abstract}
Despite the efforts of governments and firms, the construction industry is trailing other industries in labour productivity. Construction companies are interested in increasing their labour productivity, particularly when demand grows and construction firms cope with labour shortages. Off-site construction has proved to be a favourable policy to increase labour productivity. However, a complete understanding of the factors affecting construction labour productivity is lacking, and it is unclear which factors are influenced by off-site construction. This study developed a conceptual model describing how 15 factors influence the construction process and make a difference in labour productivity between off-site and on-site construction. The conceptual model shows that all 15 factors affect labour productivity in three ways: through direct effects, indirect effects and causal loops. The model is a starting point for further research to determine the impact of offsite construction on labour productivity.
\end{abstract}

\section{KEYWORDS}

Labour productivity, construction process, off-site construction, modelling.

\section{INTRODUCTION}

Productivity is an important indicator of the efficiency of an industry, company, or project. Productivity represents the relationship between the created output (e.g., number of products) and the input needed (e.g., capital, materials, labour). Companies with high productivity have advantages because they can deliver more output using as much input as their competitors do.

Productivity can be expressed in several ways, depending on which inputs are considered, such as capital, labour, energy, plant and equipment, materials, services, and overhead. Labour productivity indicates how much output is generated per work hour; it will increase by producing more with the same number of hours worked. Traditionally, production in construction is primarily dependent on human effort and performance. Jarkas and Bitar (2012) concluded that labour costs comprise $30 \%$ to $50 \%$ of the overall

1 Doctoral Researcher, Delft University of Technology, and HU University of Applied Sciences Utrecht, PO Box 182, NL-3500 AD Utrecht, The Netherlands, martin.vandijkhuizen@ @u.nl, orcid.org/00000002-5913-8915

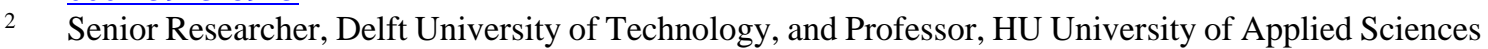
Utrecht, PO Box 5043, NL-2600 GA Delft, The Netherlands, r.vrijhoef@tudelft.nl, orcid.org/00000002-7303-838X

3 Professor, Delft University of Technology, PO Box 5048, NL-2600 GA Delft, The Netherlands, h.1.m.bakker@tudelft.nl, 
project costs. Therefore, Construction Labour Productivity (CLP) has a significant effect on project expenses and can influence the profitability of construction firms. However, despite the efforts of governments and firms, the construction industry is trailing other industries in labour productivity (Abdel-Wahab \& Vogl 2011, Stehrer et al. 2019). Construction companies are interested in how they can increase their CLP, particularly at a time when demand grows and construction firms cope with labour shortages (Bertram et al. 2019).

Vrijhoef and Van Dijkhuizen (2020) have introduced an action research approach for improving professional practice. In this approach, companies that aim for a higher CLP identify the factors that influence CLP. After that, they design an intervention for improvement. Companies can identify factors by considering the construction process as a flow that converts inputs into outputs with a minimum of waste, as shown in Drewin's (1982) conceptual model for labour productivity (Figure 1). Internal factors and external factors will influence this process. All factors affecting the conversion will influence its efficiency (i.e., CLP). An intervention can be designed based on proven policies that increase CLP, for instance, off-site construction. Vrijhoef (2016) has shown that prefabricated roofs in housing renovation projects can improve CLP. Accordingly, Eastman and Sacks (Eastman and Sacks 2008) hint at the advantages of off-site construction. They have demonstrated that CLP in off-site sectors, such as curtain wall construction, structural steel construction, and precast concrete fabrication, is about $43 \%$ higher than in on-site construction sectors.

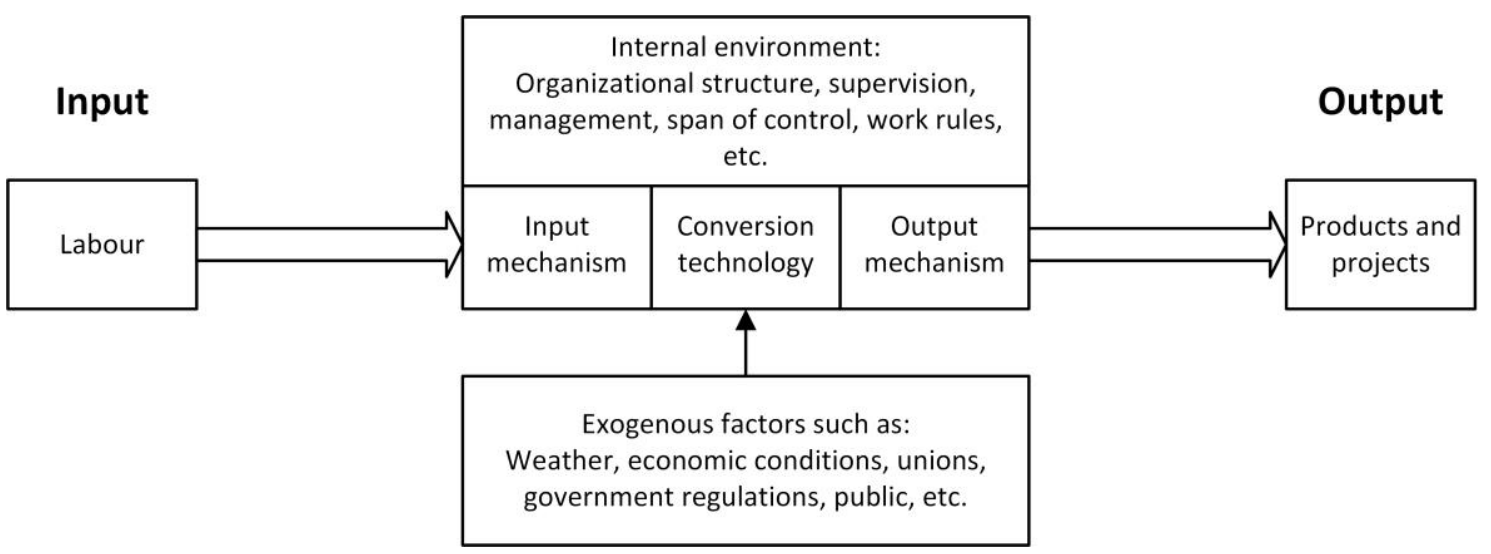

Figure 1: Conceptual model for Construction Productivity (Drewin 1982)

This paper is part of research that compares the impact on CLP of off-site and on-site construction for building projects. The study endeavours to contribute by filling two gaps found in the literature. First, it completes Drewin's model. Thomas and Sakarcan (1994) have studied the model and have noted that it does not include all potential variables that may exist. For instance, Chan et al. (2001) have concluded that literature made little mention of how the differences in the workers' abilities account for differences in productivity levels. A complete conceptual model for construction productivity can strengthen practitioners' insight into factors that can improve CLP. Completing the conceptual model is the first goal of this study.

Second, the mechanisms are unknown how off-site construction policies influence construction labour productivity. Off-site construction has many deemed advantages, such as reduced rework and less site congestion (Durdyev and Ismail 2019). However, it is unknown how these advantages influence CLP. Therefore, the second goal of this study 
is to develop a conceptual model to determine the impact of off-site construction on labour productivity.

\section{METHOD}

Literature yields two types of studies considering factors affecting CLP. First, studies that determine the influence of one or a few factors on CLP, for example, identifying the relationship between non-value-adding activities and productivity (Zhao and Chua 2003). Second, studies that list factors affecting CLP after surveying construction practitioners. A literature search on the second type resulted in 13 relevant studies (Table 1).

Table 1: Result of literature search

\begin{tabular}{|c|c|c|c|c|}
\hline & Study & Focus & Context & $\begin{array}{c}\text { Number } \\
\text { of } \\
\text { factors }\end{array}$ \\
\hline 1 & $\begin{array}{l}\text { Alinaitwe et al. } \\
\qquad(2007)\end{array}$ & Project managers & Building projects & 36 \\
\hline 2 & $\begin{array}{l}\text { Chigara and Moyo } \\
(2014)\end{array}$ & Consultants, contractors & Building projects & 40 \\
\hline 3 & Dixit et al. (2017) & Labour, management & Construction industry & 24 \\
\hline 4 & $\begin{array}{l}\text { El-Gohary and } \\
\text { Aziz (2014) }\end{array}$ & $\begin{array}{l}\text { Client, consultants, } \\
\text { contractors }\end{array}$ & Construction industry & 30 \\
\hline 5 & $\begin{array}{l}\text { Enshassi et al. } \\
\qquad(2007)\end{array}$ & Contractors & Building projects & 45 \\
\hline 6 & $\begin{array}{l}\text { Fagbenle et al. } \\
\qquad(2011)\end{array}$ & Labour, contractors & Construction industry & 12 \\
\hline 7 & $\begin{array}{l}\text { Hwang et al. } \\
\quad(2017)\end{array}$ & $\begin{array}{l}\text { Developers, contractors, } \\
\text { consultants }\end{array}$ & Green building projects & 26 \\
\hline 8 & $\begin{array}{l}\text { Jarkas and Bitar } \\
\qquad(2012)\end{array}$ & Contractors & $\begin{array}{l}\text { Building and civil } \\
\text { engineering projects }\end{array}$ & 45 \\
\hline 9 & $\begin{array}{l}\text { Kaming et al. } \\
\text { (1997) }\end{array}$ & Labour & Building projects & 11 \\
\hline 10 & $\begin{array}{c}\text { Kazaz and } \\
\text { Ulubeyli (2007) }\end{array}$ & Managers, technical staff & Construction industry & 18 \\
\hline 11 & Rivas et al. (2011) & $\begin{array}{l}\text { Labour, midlevel } \\
\text { management }\end{array}$ & Mining projects & 15 \\
\hline 12 & $\begin{array}{l}\text { Robles et al. } \\
\qquad(2014)\end{array}$ & $\begin{array}{c}\text { Companies related to } \\
\text { construction }\end{array}$ & Construction industry & 35 \\
\hline 13 & Zakeri et al. (1996) & Labour & Construction industry & 13 \\
\hline
\end{tabular}

The authors searched in five prominent journals concerning construction and project management: Construction Management and Economics, International Journal of Project Management, Journal of Construction Engineering and Management, Journal of Civil Engineering and Management, and Journal of Management in Engineering. The search string consisted of four main concepts (i.e., labour, productivity, construction, and factor) and their alternative spellings, synonyms, and alternatives within the timeframe $2009-$ 2020. The authors selected the studies that list factors influencing CLP and give insight into relations between factors and CLP, enabling to draw the cause and effect relations. 
For instance, Fagbenle et al. (2011) have concluded that participation in decision-making (cause) will affect motivation, and this will affect CLP (effect). The initial search includes the results of a limited number of journals and a limited time frame. However, the found articles refer to other relevant articles that were not in the initial search results. Therefore, those articles were added to the results. The authors used qualitative data analysis software to report factors influencing CLP and causal relations between them. Based on these articles, the model of Drewin (1982) was elaborated. After that, the authors searched in literature for advantages and disadvantages of off-site construction comparing to onsite construction. This search was combined with the model to create a new conceptual model that describes the impact of off-site construction on CLP.

\section{RESULTS}

\section{FACTORS AFFECTING LABOUR PRODUCTIVITY}

Based on the literature, the authors developed the model shown in Figure 2, in which four primary groups of factors can be distinguished. Those groups influence the efficiency of the construction process, and therefore CLP. Within each primary group and the construction process, the study identified several factors and sub-factors. Analyses of the relations between all factors and sub-factors resulted in a complicated cause and effect diagram with more than 90 variables (factors and sub-factors) and more than 100 causal links. Figure 2 summarises the causal links between the primary groups. For instance, the arrow heading from the group of external factors to the group of labour factors means that external factors and sub-factors will influence labour factors and sub-factors.

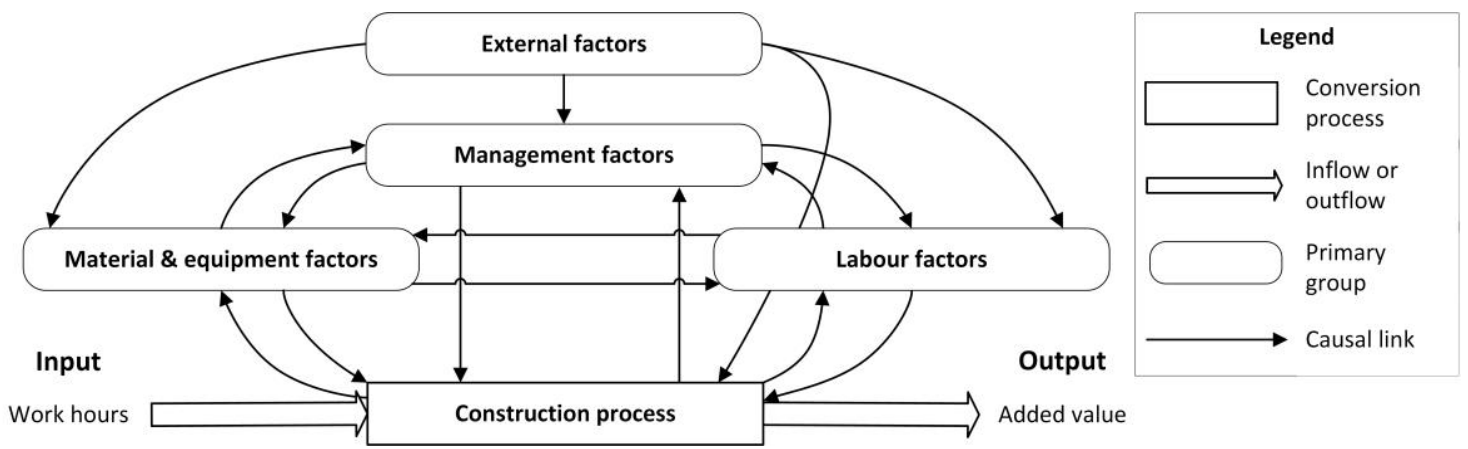

Figure 2: Conceptual model for factors influencing CLP

Table 2 shows the factors and sub-factors within the four primary groups and the construction process. The first group consists of factors that are not likely to be influenced by construction practitioners; however, this can be argued. For instance, government regulations are defined as an external factor. However, construction firms might influence this factor through a lobby. 
Table 2: Factors and sub-factors affecting labour productivity

\begin{tabular}{|c|c|c|}
\hline Factor & Sub-factors & $\begin{array}{l}\text { Mentioned in } \\
\text { studies }^{\mathrm{a}}\end{array}$ \\
\hline \multicolumn{3}{|c|}{ Primary group: External factors } \\
\hline Client & On-time payment, quality demand, trust & $1,4,5,11$ \\
\hline Site characteristics & Limited working space, restricted access & $8,10,12$ \\
\hline Surroundings & $\begin{array}{l}\text { Government regulations, weather, insecurity, } \\
\text { power \& water supply }\end{array}$ & $\begin{array}{c}1,3,4,5,6,7 \\
11,12,13\end{array}$ \\
\hline \multicolumn{3}{|c|}{ Primary group: Management factors } \\
\hline $\begin{array}{c}\text { Ability of } \\
\text { management }\end{array}$ & $\begin{array}{c}\text { Communication, competence, motivation, } \\
\text { presence }\end{array}$ & $\begin{array}{l}1,2,3,4,5,6,7 \\
8,9,11,12,13\end{array}$ \\
\hline Crew management & $\begin{array}{c}\text { Incentives, work time policy, crew composition, } \\
\text { treatment }\end{array}$ & $\begin{array}{c}1,2,3,4,5,6,7,8 \\
9,10,11,12,13\end{array}$ \\
\hline $\begin{array}{l}\text { Design \& } \\
\text { engineering } \\
\text { management }\end{array}$ & $\begin{array}{l}\text { Change orders, quality of design \& engineering, } \\
\text { time needed for design \& engineering }\end{array}$ & $\begin{array}{l}1,2,3,4,5,6,7 \\
8,9,11,12,13\end{array}$ \\
\hline $\begin{array}{l}\text { Financial } \\
\text { management }\end{array}$ & Financing possibilities, liquidity & $1,2,3,4,5,7$ \\
\hline $\begin{array}{l}\text { Health \& safety } \\
\text { management }\end{array}$ & Safety measures, working climate & $\begin{array}{c}2,3,4,5,9,10 \\
11,12,13\end{array}$ \\
\hline $\begin{array}{l}\text { Construction } \\
\text { coordination }\end{array}$ & $\begin{array}{l}\text { Research \& development, facilitation, schedule } \\
\text { change, contract type, timely interventions }\end{array}$ & $\begin{array}{l}1,2,3,4,5,6,7 \\
8,9,11,12,13\end{array}$ \\
\hline $\begin{array}{l}\text { Supply chain } \\
\text { management and } \\
\text { logistics }\end{array}$ & Quality of transportation, storage, distribution & $\begin{array}{l}2,3,4,5,6,8 \\
9,11,12,13\end{array}$ \\
\hline $\begin{array}{l}\text { Tool \& equipment } \\
\text { management }\end{array}$ & Maintenance policy, substitution policy & $1,2,11,13$ \\
\hline \multicolumn{3}{|c|}{ Primary group: Labour factors } \\
\hline Behaviour & Absenteeism, effort, turnover & $\begin{array}{c}1,2,3,4,5,6,7,8 \\
9,10,11,12,13\end{array}$ \\
\hline $\begin{array}{l}\text { Characteristics \& } \\
\text { traits }\end{array}$ & $\begin{array}{l}\text { Age, crew availability, crew size, fatigue, health, } \\
\text { intelligence, values, personal circumstances, } \\
\text { learning speed, confidence, integrity, loyalty }\end{array}$ & $\begin{array}{c}1,2,3,4,5,6,7,8 \\
9,10,11,12,13\end{array}$ \\
\hline Motivation & Satisfaction, distraction, sense of pride & $2,5,7,8,10,11,12$ \\
\hline Skills & $\begin{array}{l}\text { Flexibility, preparedness, communication, } \\
\text { reaction time, resourcefulness, efficiency, } \\
\text { experience, literacy, management skills }\end{array}$ & $\begin{array}{l}1,2,3,4,5,6,7 \\
8,9,11,12,13\end{array}$ \\
\hline \multicolumn{3}{|c|}{ Primary group: Material \& equipment factors } \\
\hline Materials & $\begin{array}{l}\text { Availability, congestion, quality of materials, } \\
\text { sabotage, capacity of manufacturing industry }\end{array}$ & $\begin{array}{l}1,2,3,4,5,7,8 \\
9,11,12,13\end{array}$ \\
\hline Tools \& equipment & $\begin{array}{l}\text { Availability, quality of tools \& equipment, site } \\
\text { lay-out }\end{array}$ & $\begin{array}{l}1,2,3,4,5,6 \\
7,11,12,13\end{array}$ \\
\hline Construction process & $\begin{array}{l}\text { Method, overcrowding, quality of work, quantity } \\
\text { of work, rework, schedule pressure, waiting time }\end{array}$ & $\begin{array}{c}1,2,3,4,5,7,8 \\
9,11,12,13\end{array}$ \\
\hline
\end{tabular}

${ }^{a}$ Following the numbering in Table 1 
The second group contains management factors. Managers influence the construction process directly or indirectly through labour factors or material and equipment factors. They provide their subordinates with guidelines for making decisions, also called policies. The authors distinguish policies in seven different fields, but first of all, the chosen policy will only be effective with the presence and adequate ability of the managers. For instance, poor instructions cause low quality of work, and this can cause rework (Zakeri et al. 1996). All 13 studies refer to the manager's competence, education level, motivation, and communication skills as essential sub-factors.

To influence labour, managers can choose several policies. They influence labour motivation by financial incentives such as remuneration (Kazaz and Ulubeyli 2007) or non-financial incentives such as offering promotion opportunities, job security, and recognition (Rivas et al. 2011). Managers can influence the material and equipment factors by choosing the right supply chain management policy. Just-in-time delivery will prevent material buffers (Horman and Thomas 2005), but it can cause waiting time when not properly executed (Alinaitwe et al. 2007). Material buffers will prevent waiting time, but they can cause more time to spend on logistics (Dixit et al. 2017).

The third group includes labour-related factors such as motivation and absenteeism. Workers influence the conversion of input into output, but they also affect management and material and equipment factors. For instance, labour commitment determines the effectiveness of a management policy and the quality of equipment maintenance. The motivation of labourers is of significant influence because motivated labourers usually are enthusiastic, take the initiative, work hard and respond fast to instructions, making them more productive than demotivated or discouraged labourers (Jarkas and Bitar 2012). Some studies rate absenteeism as a top factor (Dixit et al. 2017, Kaming et al. 1997), while Chigara and Moyo (2014) see little influence. This difference can be explained by realising that managers will neglect absent workers as input if the absent workers do not get paid. In this case, absenteeism will not (directly) influence the output-input ratio.

The fourth group embodies factors concerning materials and equipment, such as their availability and quality. They influence the construction process directly or indirectly by affecting the effectiveness and efficiency of labour and management. Material, tools and equipment shortages cause workers' idle time (Alinaitwe et al. 2007). Causes of material shortages include on-site transportation difficulty, poor supply chain management (Kaming et al. 1997), incorporating not locally manufactured materials in design, and insufficient manufacturing industry capacity (Chigara and Moyo 2014). Causes of tools and equipment shortages include tools and equipment breakdown and expensive tool and equipment prices (Chigara and Moyo 2014).

Finally, the study distinguished several factors within the construction process. Quality of work (Dixit et al. 2017) and continuous changes and improvements of construction method (Fagbenle et al. 2011) will increase CLP, while overcrowding, rework (El-Gohary and Aziz 2014, Enshassi et al. 2007, Robles et al. 2014), and schedule pressure or work overload (Dixit et al. 2017) have a negative effect.

\section{OFF-SITE CONSTRUCTION'S IMPACT ON CLP}

Several studies describe the advantages and disadvantages of off-site construction. Within the advantages and disadvantages, the authors selected elements that match factors and sub-factors of Table 2. Those (sub-)factors might be responsible for the difference in CLP between off-site and on-site construction. Figure 3 represents an overview of the factors and sub-factors found. 


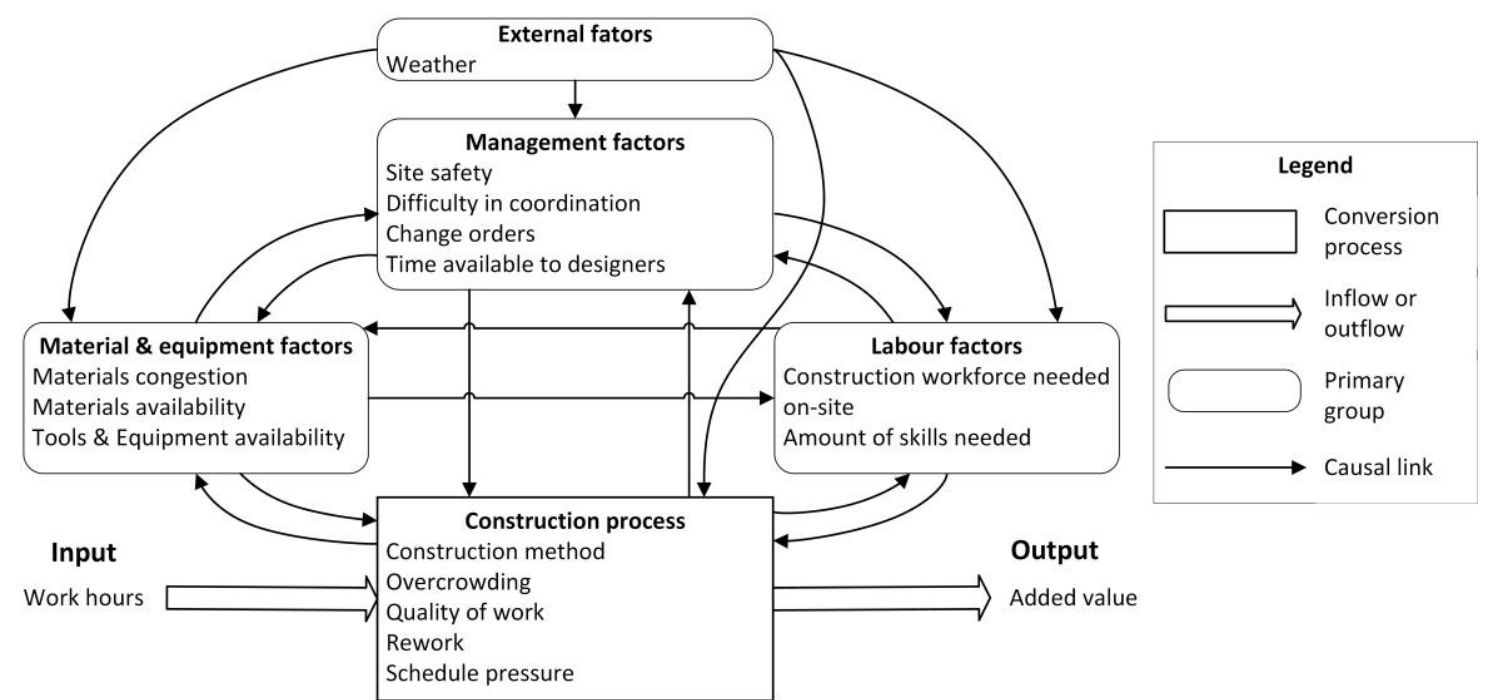

Figure 3: Conceptual model for determining the impact of off-site construction on labour productivity

Off-site construction in a factory hall is independent of weather (Antillón et al. 2014, Gibb and Isack 2003). This can affect the construction process directly because the loss of quality and time due to harsh weather can be avoided. It can also indirectly influence the construction process because weather conditions can damage building materials (Chauhan et al. 2019), decreasing material availability. Due to less time spent on site, the risk of weather-related accidents is also lower (Durdyev and Ismail 2019). Less time spent on site will limit absenteeism due to mishaps.

Within the group of management factors, two advantages occur with off-site construction. First, management can experience a decrease in coordination between subcontractors and different trades (Antillón et al. 2014), allowing them to put more time into crew coordination. Second, factory-controlled fabrication improves construction safety performance on site (Durdyev and Ismail 2019). Antillón et al. (2014) and Chauhan et al. (2019) expect a higher safety of off-site construction due to reduced dangerous working conditions and less traffic. Off-site construction also has some disadvantages affecting CLP negatively. Off-site construction requires a more detailed design and more time for designers (Chauhan et al. 2019). In case of a tight schedule, this might influence the quality of design, drawings and specifications, influencing the quality of work. Offsite construction is also less flexible than on-site construction. Late customer changes are not possible (Chauhan et al. 2019). In the case of regular change orders, off-site construction is at a disadvantage compared to on-site production. In the worst case, production will have to stop, causing waiting time. Nevertheless, also without change orders, off-site production is less flexible. Off-site construction products such as precast concrete have to be ordered ahead of time. However, the construction process is very volatile, disallowing contractors to predict the quantities in advance accurately. The contractor might not install all requested precast elements, thus building up unneeded inventory on-site (Ballard et al. 2003).

The study found two advantages of off-site construction concerning labour factors. Durdyev and Ismail (2019) mention that less construction workforce is involved on-site, influencing CLP on-site. However, the off-site fabrication process needs more labour input. Therefore, no conclusion can be made if off-site construction needs more or less workforce and if this difference will cause less CLP. Also, the amount of skills needed 
for off-site construction is assumed to be less than constructing on-site (Durdyev and Ismail 2019). The number of skills can positively affect CLP because the production process will be less dependent on specialists. On the other hand, it can negatively affect CLP because workers' motivation might decrease when workers are not challenged.

A controlled factory environment can lower the risk of material congestion (Gibb and Isack 2003). Material congestion will compel labour to search for materials or move others to reach the materials needed. Off-site construction requires fewer materials, tools and equipment on-site (Durdyev and Ismail 2019), which may affect the availability.

The study distinguished five sub-factors within the construction process that will influence CLP in off-site construction. The construction methods accompanying off-site construction provide controlled work heights, tool weights, and environmental conditions (Chauhan et al. 2019). Fewer workers are needed on-site, which will prevent overcrowding (Durdyev and Ismail 2019). The quality of the work done is generally higher (Gibb and Isack 2003). High quality of work will decrease rework (Gibb and Isack 2003). Finally, off-site construction gives the opportunity to pre-plan the work, lowering the schedule pressure (Durdyev and Ismail 2019).

\section{CONCLUSION}

This paper focused on the factors affecting construction labour productivity and which are influenced by off-site construction. This study analysed 13 articles that list factors affecting construction labour productivity after surveying construction practitioners. The analysis resulted in a complicated cause and effect diagram. The study summarised the diagram into a conceptual model representing the relations between the construction process and four primary groups: external factors, management factors, labour factors, and material and equipment factors. Next, a literature search yielded the advantages and disadvantages of off-site construction. Fifteen of the advantages and disadvantages of offsite construction can affect labour productivity.

The conceptual model shows that all 15 factors affect labour productivity in three ways: through direct effects, indirect effects and causal loops. The factors affect labour productivity directly by influencing the efficiency of the construction process. On the other hand, the factors affect labour productivity indirectly through other factors. For instance, off-site construction in a factory hall protects materials from weather influences, keeping them intact and available. This prevents workers from waiting for materials, enabling them to continue the construction process. The model also shows that the factors and links can invoke causal loops. This can cause a reinforcing or balancing effect on productivity. For example, the limited skills needed for off-site construction can make the work less challenging. Unchallenging work can decrease workers' motivation which results in a lower quality of work. Low quality of work can demotivate the workers even more. Further research concerning off-site construction's impact on labour productivity will focus on the 15 factors. However, the indirect effects and causal loops compel researchers to consider the intermediate factors, such as labour motivation.

This model helps to understand the relations between factors in the primary groups, construction process, and labour productivity. Further research is needed to handle the study's limitations. First, this study is based on surveys concerning different project types in different countries. In future studies, construction practitioners can confirm, reject or add factors to ensure validity for specific projects under specific circumstances. Second, the conceptual model can be elaborated to give insight into the relations between factors within the primary groups and the construction process. Third, the qualitative model can 
be refined into a quantitative model. And fourth, the model can be tested with empirical data. For now, the conceptual model is a start to study the impact of off-site construction on construction labour productivity.

\section{REFERENCES}

Abdel-Wahab, M., and Vogl, B. (2011). 'Trends of productivity growth in the construction industry across Europe, US and Japan'. Construction Management and Economics, 29(6), 635-644.

Alinaitwe, H. M., Mwakali, J. A., and Hansson, B. (2007). 'Factors affecting the productivity of building craftsmen - studies of Uganda'. Journal of Civil Engineering and Management, 13(3).

Antillón, E. I., Morris, M. R., and Gregor, W. (2014). 'A value-based cost-benefit analysis of prefabrication processes in the healthcare sector: A case study'. 22nd Annual Conference of the International Group for Lean Construction: Understanding and Improving Project Based Production, IGLC 2014, 995-1006.

Ballard, G., Harper, N., and Zabelle, T. (2003). 'Learning to see work flow: An application of lean concepts to precast concrete fabrication'. Engineering, Construction and Architectural Management, 10(1), 6-14.

Bertram, N., Fuchs, S., Mischke, J., Palter, R., Strube, G., and Woetzel, J. (2019). Modulair Construction: From projects to products. McKinsey \& Company.

Chan, P., Puybaraud, M. C., and Kaka, A. (2001). 'Construction training: A linkage to productivity improvements'. 17th Annual ARCOM Conference, 5-7 September 2001, A. Akintoye, ed., University of Salford. Association of Researchers in Construction Management, Salford, 143-55.

Chauhan, K., Peltokorpi, A., Lavikka, R., and Seppänen, O. (2019). 'Deciding Between Prefabrication and On-Site Construction: A Choosing-by-Advantage Approach'. 27th Annual Conference of the International Group for Lean Construction, IGLC 2019, 749-758.

Chigara, B., and Moyo, T. (2014). 'Factors Affecting Labor Productivity on Building Projects in Zimbabwe'. International Journal of Architecture, Engineering and Construction, 3(1).

Dixit, S., Mandal, S., Pandey, A., and Bansal, S. (2017). 'A study of enabling factors affecting construction productivity: Indian scnerio.' International Journal of Civil Engineering and Technology, 8(6), 741-758.

Drewin, F. J. (1982). Construction productivity: measurement and improvement through work study. Elsevier, New York.

Durdyev, S., and Ismail, S. (2019). 'Offsite Manufacturing in the Construction Industry for Productivity Improvement'. Engineering Management Journal, 31(1), 35-46.

Eastman, C. M., and Sacks, R. (2008). 'Relative Productivity in the AEC Industries in the United States for On-Site and Off-Site Activities'. Journal of Construction Engineering and Management, 134(7), 517-526.

El-Gohary, K. M., and Aziz, R. F. (2014). 'Factors Influencing Construction Labor Productivity in Egypt'. Journal of Management in Engineering.

Enshassi, A., Mohamed, S., Mustafa, Z. A., and Mayer, P. E. (2007). 'Factors affecting labour productivity in building projects in the Gaza strip'. Journal of Civil Engineering and Management. 
Fagbenle, O. I., Ogunde, A. O., and Owolabi, J. D. (2011). 'Factor Affecting the Performance of Labour in Nigerian Construction Sites'. Mediterranean journal of social sciences, 2(2).

Gibb, A., and Isack, F. (2003). 'Re-engineering through pre-assembly: client expectations and drivers'. Building Research \& Information, 31(2), 146-160.

Horman, M. J., and Thomas, H. R. (2005). 'Role of Inventory Buffers in Construction Labor Performance'. Journal of Construction Engineering and Management, 131(7), 834-843.

Hwang, B.-G., Zhu, L., and Ming, J. T. T. (2017). 'Factors Affecting Productivity in Green Building Construction Projects: The Case of Singapore'. Journal of Management in Engineering.

Jarkas, A. M., and Bitar, C. G. (2012). 'Factors Affecting Construction Labor Productivity in Kuwait'. Journal of Construction Engineering and Management.

Kaming, P. F., Olomolaiye, P. O., Holt, G. D., and Harris, F. C. (1997). 'Factors influencing craftsmen's productivity in Indonesia'. International Journal of Project Management, 15(1), 21-30.

Kazaz, A., and Ulubeyli, S. (2007). 'Drivers of productivity among construction workers: A study in a developing country'. Building and Environment, 42(5), 2132-2140.

Rivas, R. A., Borcherding, J. D., González, V., and Alarcón, L. F. (2011). 'Analysis of Factors Influencing Productivity Using Craftsmen Questionnaires: Case Study in a Chilean Construction Company'. Journal of Construction Engineering and Management.

Robles, G., Stifi, A., Ponz-Tienda, J. L., and Gentes, S. (2014). 'Labor productivity in the construction industry - Factors influencing the Spanish construction labor productivity.' International Journal of Civil, Architectural, Structural and Construction Engineering, 8(10), 999-1008.

Stehrer, R., Bykova, A., Jäger, K., Reiter, O., and Schwarzhappel, M. (2019). Industry level growth and productivity data with special focus on intangible assets, wiiw Statistical Report No. 8.

Thomas, H. R., and Sakarcan, A. S. (1994). 'Forecasting Labor Productivity Using Factor Model'. Journal of Construction Engineering and Management, 120(1), 228-239.

Vrijhoef, R. (2016). 'Effects of Lean Work Organization and Industrialization on Workflow and Productive Time in Housing Renovation Projects'. 24th Annual Conference of the International Group for Lean Construction, Boston, MA.

Vrijhoef, R., and Van Dijkhuizen, M. (2020). 'Lean Toolbox Approach for Effective Preparation of Housing Refurbishment Projects Using Critical Success Factors'. Proc. 28th Annual Conference of the International Group for Lean Construction (IGLC28), I. D. Tommelein and E. Daniel, eds., Berkeley, CA, 181-192.

Zakeri, M., Olomolaiye, P. O., Holt, G. D., and Harris, F. C. (1996). 'A survey of constraints on Iranian construction operatives' productivity'. Construction Management and Economics, 14(5), 417-426.

Zhao, Y., and Chua, D. K. H. (2003). 'Relationship Between Productivity and Non ValueAdding Activities'. 11th Annual Conference of the International Group for Lean Construction, Singapore. 